\title{
2020-2021 Vegetable Production Handbook: Chapter 2. Fertilizer Management for Vegetable Production in Florida ${ }^{1}$
}

\author{
Guodong Liu, Eric H. Simonne, Kelly T. Morgan, George J. Hochmuth, Shinsuke Agehara, and \\ Rao Mylavarapu²
}

\section{Best Management Practices}

With the passage of the Federal Clean Water Act (FCWA) in 1972, states were required to assess the impacts of agricultural fertilizer use on surface and ground waters. The FCWA also requires states to identify impaired water bodies and establish the amount of fertilizer nutrient that can enter a water body consistent with its intended use (swimming, fishing, or potable uses), called total maximum daily loads (TMDLs). Water quality TMDLs involving vegetable production are concentrations of nitrate, phosphate, and total dissolved solids. Best Management Practices (BMPs) are specific cultural practices aimed at reducing the load of specific fertilizer compounds entering ground and surface water while maintaining or increasing economical yields. BMPs are intended to be economically sound, cost effective, and environmentally friendly based on scientific output. It is important to recognize that BMPs do not aim at becoming an obstacle to vegetable production. Instead, they should be viewed as a means to balance economical vegetable production with environmental responsibility.

The BMPs that will apply to vegetable production in Florida are described in Water Quality/Quantity Best Management
Practices for Florida Vegetable and Agronomic Crops, produced by the Florida Department of Agriculture and Consumer Services (FDACS). This manual was developed through a cooperative effort between state agencies, water management districts, and commodity groups, and under the scientific leadership of the University of Florida Institute of Food and Agricultural Sciences (UF/IFAS). The manual was adopted by reference in 2006 and by rule in Florida Statutes (5M-8 Florida Administrative Code) and was revised in 2015 (https://www.fdacs.gov/content/download/77230/file/vegAgCropBMP-loRes.pdf). Vegetable growers may get one-on-one consultation on 1) the benefits from joining the BMP program, 2) how to join it, 3) how to select the BMPs that apply to their operation, and 4) how to meet the requirements, by contacting their local UF/IFAS Extension agent.

The vegetable BMPs have adopted all current UF/IFAS recommendations, including those for fertilizer and irrigation management (see the new BMP manual on "Optimum Fertilizer Management”). At the field level, adequate fertilizer rates should be used together with proper irrigation scheduling techniques and crop nutritional status monitoring tools (leaf analysis, petiole sap testing). In the

1. This document is CV296, one of a series of the Horticultural Sciences Department, UF/IFAS Extension. Original publication date June 2015. Revised June 2020. Visit the EDIS website at http://edis.ifas.ufl.edu.

2. Guodong Liu, assistant professor, Horticultural Sciences Department; Eric H. Simonne, Northeast District Extension director; Kelly T. Morgan, professor; George J. Hochmuth, professor emeritus, Department of Soil and Water Sciences, UF/IFAS Southwest Florida Research and Education Center; Shinsuke Agehara, assistant professor, Horticultural Sciences Department, UF/IFAS Gulf Coast REC; and Rao Mylavarapu, professor, Department of Soil and Water Sciences; UF/IFAS Extension, Gainesville, FL 32611.

The Institute of Food and Agricultural Sciences (IFAS) is an Equal Opportunity Institution authorized to provide research, educational information and other services

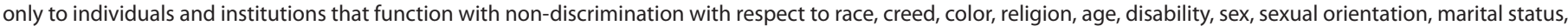

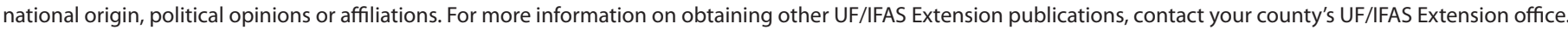
U.S. Department of Agriculture, UF/IFAS Extension Service, University of Florida, IFAS, Florida A \& M University Cooperative Extension Program, and Boards of County Commissioners Cooperating. Nick T. Place, dean for UF/IFAS Extension. 
BMP manual, adequate fertilizer rates may be achieved by combinations of UF/IFAS-recommended basal rates and supplemental fertilizer applications added after leaching by rainfall, when tissue analyses suggest a need for more fertilizer, or when the harvesting season is prolonged.

\section{Soils}

Vegetables are grown in various soil types throughout the state. These soil types include sandy soils, sandy loam soils, Histosols (organic muck), and calcareous marl soils. Sandy soils make up the dominant soil type for vegetable production in Florida. Vegetables are produced on sandy soils throughout the Florida peninsula and on sandy soils and sandy loams in the panhandle. Sandy soils have some advantages, such as ease of tillage, production of the earliest vegetable crops, and timely production operations, but they have disadvantages as well, including leaching mobile nutrients such as nitrogen, potassium, and even phosphorus by heavy rain or excessive irrigation. Therefore, sandy soils must be managed carefully regarding fertilization programs and irrigation scheduling. Histosols, calcareous rocky soils, and marl soils are also important for Florida's vegetable production. For more information, please see Soil and Fertilizer Management for Vegetable Production in Florida at https://edis.ifas.ufl.edu/cv101.

\section{Soil Preparation}

A well-prepared planting bed is important for uniform stand establishment of vegetable crops. Previous crop residues and weeds should be plowed down well in advance of crop establishment. A 6-to-8-week period between plowing down of green cover crops and crop establishment is recommended to allow the decay of the residues. Freshly incorporated plant material promotes high levels of damping-off organisms, such as Pythium spp. and Rhizoctonia spp. Turning under plant residue well in advance of cropping reduces damping-off disease organisms. Land should be kept disked if necessary to keep new weed cover from developing prior to cropping.

Chisel plowing is beneficial in penetrating and breaking tillage hardpan layers in fields. If plastic mulch culture is practiced, debris and large undecayed roots may create problems in preparing good beds over which mulch will be applied. For more information about soil preparation for commercial vegetable production, see Soil Preparation and Liming for Vegetable Gardens at https://edis.ifas.ufl.edu/ vh024.

\section{Liming}

Current UF/IFAS recommendations call for maintaining soil $\mathrm{pH}$ between 6.0 and 6.5 (Table 1); further discussion is in Soil pH Range for Optimum Commercial Vegetable Production at https://edis.ifas.ufl.edu/hs1207. If soil $\mathrm{pH}$ is too low, liming is needed. A common problem in Florida has been overliming, resulting in high soil $\mathrm{pH}$ tying up micronutrients and phosphorus, causing a restriction of their uptake by plants. Overliming can also reduce the accuracy with which a soil test can predict the fertilizer component of the Crop Nutrient Requirement (CNR). For more information about liming, see Liming of Agronomic Crops at https://edis.ifas.ufl.edu/aa128. Liming can not only adjust soil $\mathrm{pH}$ but also provide calcium and magnesium if dolomite (i.e., calcium magnesium carbonate) is used.

Irrigation water from wells in limestone aquifers is an additional source of liming material. The combination of liming and use of alkaline irrigation water has resulted in soil $\mathrm{pH}$ greater than 7.0 for many sandy soils in Florida. To measure the liming effect of irrigation, have a water sample analyzed for total bicarbonates and carbonates annually and the results converted to pounds of calcium carbonate per acre. Liming (Table 2), fertilization (Table 3), and irrigation programs are closely related to each other. To maximize overall production efficiency, soil and water testing in a critical BMP must be made a part of any fertilizer management program. Additionally, using ammoniacal fertilizers can neutralize alkalinity (Table 3 ), but nitrate fertilizers can increase $\mathrm{pH}$ in the root zone due to selective uptake of differentiations by plants. Fertigation with ammonium-N (such as ammonium sulfate) is effective for decreasing soil $\mathrm{pH}$, but volatilization may be a concern.

\section{Bedding}

Fields where seepage irrigation is used, fields prone to flooding, or fields where the soil profile is too shallow should be cropped using raised beds. Beds generally range from 3 to 8 inches in height, with high beds of 6 to 8 inches preferred where risk of flooding is greatest. Raised beds dry faster than nonbedded soils. Raised beds promote earlyseason soil warming, resulting in somewhat earlier crops during cool seasons. Mulching requires a smooth, wellpressed bed for efficient heat transfer from black mulch to the soil. Adequate soil moisture is essential in forming a good bed for mulching using a bed press.

\section{Fertilization}

Fertilization is essentially needed for vegetable production in Florida. A new and innovative approach to BMPs for 
fertilization known as $\mathbf{4 R}$ nutrient stewardship is defined as follows: the RIGHT fertilizer SOURCE is applied at the RIGHT RATE in the RIGHT PLACE and at the RIGHT TIME to a crop. More information about the 4Rs is available in What is $4 R$ Nutrient Stewardship? at https://edis.ifas. ufl.edu/hs1264 and The Four Rs of Fertilizer Management at http://edis.ifas.ufl.edu/ss624. For tomato production, more information is available in Implementing the Four Rs (4Rs) in Nutrient Stewardship for Tomato Production at https:// edis.ifas.ufl.edu/hs1269.

\section{Right Rate}

\section{Soil Testing}

Soil testing is a key BMP for nutrient management. There are 17 elements essential to plant growth (Table 4). Nickel is the 17th element (see Nickel Nutrition in Plants at https:// edis.ifas.ufl.edu/hs1191).The crop nutrient requirement (CNR) for a particular element is defined as the total amount in $\mathrm{lb} / \mathrm{A}$ of that element needed by the crop to produce optimum economic yield. The CNR can be satisfied from many sources, including soil, water, air, organic matter, or fertilizer.

The CNR for a crop has been determined from field experiments that test the yield response to selected levels of added fertilizer. The CNR is equivalent to the fertilizer rate above which no significant increase in yield is expected. The CNR values derived from such experiments take into account factors such as fertilizer efficiencies of the soils and cultural practices. Using the CNR concept will ensure optimum economic returns and minimize both pollution from overfertilization and loss of yield due to underfertilization.

It is important to remember that nutrients are supplied to the crop from both the soil and fertilizer. The amounts are applied as fertilizers only when a properly calibrated soil test indicates limited amounts of extractable macronutrients ( $\mathrm{N}, \mathrm{P}, \mathrm{K}, \mathrm{Mg}$, and $\mathrm{Ca}$ ) or micronutrients present in the soil. Decisions should be based on two common extractants used by commercial laboratories (Mehlich-1 or Mehlich-3 for $\mathrm{P}, \mathrm{K}, \mathrm{Mg}$, and $\mathrm{Ca}$; however, Mehlich-3 provides better results for soils with a $\mathrm{pH}$ of 7 or greater. More information about Mehlich-3 is available in Extraction of Soil Nutrients Using Mehlich-3 Reagent for Acid-Mineral Soils of Florida at https://edis.ifas.ufl.edu/ss620. Based on such tests, the amount of fertilizer that is needed to supplement the nutrition component of the native soil can be calculated. The BMP program for vegetables requires a calibrated soil test. More information about soil testing can be found in Developing a Soil Test Extractant: The Correlation and
Calibration Processes at https://edis.ifas.ufl.edu/ss622 and Soil Testing for Plant-Available Nutrients-What Is It and Why Do We Use It? at https://edis.ifas.ufl.edu/ss621.

\section{Plant Tissue Analysis}

Analysis of plant tissues (e.g., leaves or petioles) for nutrient concentration provides a good tool to monitor nutrient management programs. There are basically two approaches to plant tissue testing: standard laboratory analysis and the plant sap testing procedures. Standard laboratory analysis involves analyzing the most recently matured leaf of the plant for an array of nutrients. The resulting analyses are compared against published adequate ranges for that particular crop. Laboratory results that fall outside the adequate range for that nutrient may indicate either a deficiency or possibly toxicity (especially in the case of micronutrients). The most recently matured leaf serves well for routine crop monitoring and diagnostic procedures for most nutrients. However, for the immobile nutrients such as $\mathrm{Ca}, \mathrm{B}$, and certain other micronutrients, younger leaves are generally preferred.

The second approach is use of plant sap quick-test kits that have been calibrated for $\mathrm{N}$ and $\mathrm{K}$ for several vegetables in Florida. These testing kits analyze fresh plant sap for $\mathrm{N}$ and K. Quick tests can be a valuable tool for on-the-spot monitoring of plant nutrient status. Diagnostic information for leaf and petiole sap testing can be found in Plant Tissue Analysis and Interpretation for Vegetable Crops in Florida at https://edis.ifas.ufl.edu/ep081 and Petiole Sap Testing for Vegetable Crops at https://edis.ifas.ufl.edu/cv004.

\section{Right Source}

\section{N, P, K, Nutrient Rates and Sources}

Nitrogen often is the most limiting nutrient in Florida's sandy soils. The amount of nitrogen required by vegetable plants must be applied each growing season because it leaches rapidly. Therefore, crop nitrogen requirements vary among crops and are not dependent on soil test results (Table 5). Fertilizer rates of other nutrients must be applied based on soil test results (see soil test above) to follow BMPs. The interpretations of Mehlich-1 (very low, low, medium, high, and very high) and Mehlich-3 (low, medium, and high) are shown in Table 6 . The soil test extractant used in UF/IFAS recommendations recently has changed to Mehlich-3. UF recommendations based on Mehlich-3 test include $\mathrm{P}_{2} \mathrm{O}_{5}$ and $\mathrm{K}_{2} \mathrm{O}$ (Table 7) and nutrient management using fertigation (Table 8). More information on the change to Mehlich-3 can be found in Extraction of Soil Nutrients Using Mehlich-3 Reagent for Acid-Mineral Soils of Florida at 
https://edis.ifas.ufl.edu/ss620. Some private companies may use Mehlich-1 and recommendations include $\mathrm{P}_{2} \mathrm{O}_{5}$ and $\mathrm{K}_{2} \mathrm{O}$ (Table 9) and micronutrients (Table 10).

The recommendations found in Tables 7 through 10 were determined in field rate studies considering a wide range of nutrient applications and various soil $\mathrm{pH}$ levels. Crop plant development, crop yield, and vegetable quality were considered in determining the optimum nutrient levels for UF/IFAS recommendations.

Nitrogen $(\mathrm{N})$ can be supplied in both nitrate and ammoniacal forms. Nitrate-nitrogen is generally the preferred form for plant uptake in most situations, but ammoniacal $\mathrm{N}$ can be absorbed directly or after conversion to nitrate- $\mathrm{N}$ by soil microbes. Because this rate of conversion is reduced in cold, fumigated, or strongly acidic soils, it is recommended that under such conditions $25 \%$ to $50 \%$ of the $\mathrm{N}$ be supplied from nitrate sources. This ratio is not critical for unfumigated or warm soils.

Phosphorus (P) can be supplied from several sources, including single and triple superphosphate, diammonium phosphate (DAP) and monoammonium phosphate (MAP), and monopotassium phosphate. All sources can be effective for plant nutrition. However, on soils that test very low in native micronutrient levels, DAP in mixtures containing micronutrients reduces yields when banded in large amounts. Initial soil reaction $\mathrm{pH}$ with DAP is about 8.5, which favors ammonia production and volatilization. This produced ammonia causes seedling injury and inhibits root growth. Adequate separation of seed and DAP is needed to eliminate any seedling damage. DAP should not be used on calcareous or high-pH soils. MAP's reaction $\mathrm{pH}$ is 3.5 and does not have the above problems.

Potassium (K) can also be supplied from several sources, including potassium chloride, potassium sulfate, potassium nitrate, and potassium-magnesium sulfate. If adhering to amounts of $\mathrm{K}$ fertilizer predicted by soil tests, there should be no concern about the $\mathrm{K}$ source or its relative salt index.

\section{Ca, Mg, S Nutrient Rates and Sources}

The secondary nutrients calcium $(\mathrm{Ca})$, magnesium $(\mathrm{Mg})$, and sulfur (S) have not been a common problem in Florida. Calcium usually occurs in adequate supply for most vegetables when the soil is limed. Because we do not have an interpretation for Mehlich-3 soil Ca yet, we still have Mehlich-1 soil Ca interpretation. If the Mehlich-1 soil Ca index is above $300 \mathrm{ppm}$, it is unlikely that there will be a response to added Ca. Maintaining correct moisture levels in the soil by irrigation will aid in Ca supply to the roots. Calcium is not mobile in the plant; therefore, foliar sprays of $\mathrm{Ca}$ are not likely to correct deficiencies. It is difficult to place enough foliar-applied $\mathrm{Ca}$ at the growing point of the plant on a timely basis.

Magnesium deficiency may be a problem for vegetable production; however, when the Mehlich-3 soil-test index for $\mathrm{Mg}$ is below $23 \mathrm{ppm}, 30-40 \mathrm{lb} \mathrm{Mg} / \mathrm{A}$ will satisfy the $\mathrm{Mg}$ CNR. If lime is also needed, $\mathrm{Mg}$ can be added by using dolomite as the liming material. If no lime is needed, then the $\mathrm{Mg}$ requirement can be satisfied through use of magnesium sulfate or potassium-magnesium sulfate. Blending of the $\mathrm{Mg}$ source with other fertilizer(s) to be applied to the soil is an excellent way of ensuring uniform application of $\mathrm{Mg}$ to the soil.

Sulfur deficiencies have seldom been documented for Florida vegetables. Sulfur deficiency would most likely occur on deep, sandy soils low in organic matter after leaching rains. If $S$ deficiency has been diagnosed, it can be corrected by using S-containing fertilizers, such as magnesium sulfate, ammonium sulfate, potassium sulfate, normal superphosphate, or potassium-magnesium sulfate. Using one of these materials in the fertilizer blends at levels sufficient to supply 30 to $40 \mathrm{lb} \mathrm{S/A}$ should prevent S deficiencies.

\section{Micronutrient Sources}

It has been common in Florida vegetable production to routinely apply a micronutrient package. This practice has been justified on the basis that these nutrients were inexpensive and their application appeared to be insurance for high yields. In addition, there was little research data and a lack of soil-test calibrations to guide judicious application of micronutrient fertilizers. Compounding the problem has been the vegetable industry's use of micronutrientcontaining pesticides for disease control.

Copper $(\mathrm{Cu})$, manganese $(\mathrm{Mn})$, and zinc $(\mathrm{Zn})$ from pesticides have tended to accumulate in the soil. This situation has forced some vegetable producers to overlime in an effort to reduce availability and avoid micronutrient toxicities. Data have now been accumulated that permit a more accurate assessment of micronutrient requirements (Table 10). Growers are encouraged to have a calibrated micronutrient soil test conducted and to refrain from "shotgun" micronutrient fertilizer applications. It is unlikely that micronutrient fertilizers will be needed on old vegetable land, especially where micronutrients are being applied regularly via recommended pesticides. A micronutrient soil 
test every 2 to 3 years will provide recommendations for micronutrient levels for crop production.

\section{Manures and Composts}

Waste organic products, including animal manures and composted organic matter, contain nutrients for enhancing plant growth. These materials applied to the soil decompose releasing nutrients for vegetable crops to utilize. The application of these materials has to comply with food safety requirements, such as Produce Safety Alliance (PSA). The key to proper use of organic materials as fertilizers comes in the knowledge of the nutrient content and the decomposition rate of the material. Growers contemplating using organic materials as fertilizers should have an analysis of the material before determining the rate of application. In the case of materials such as sludges, it is important to have knowledge about the type of sludge to be used. Certain classes of sludge are not appropriate for vegetable production, and in fact, sludge is not permitted for land application in vegetable production. Decomposition rates of organic materials are rapid in warm, sandy soils in Florida. Therefore, there will be relatively small amounts of residual nutrients remaining for succeeding crops. Usually application rates of organic wastes are determined largely by the $\mathrm{N}$ content. Organic waste materials can contribute to groundwater or surface water pollution if applied in rates in excess of the CNR for a particular crop. Therefore, it is important to understand the nutrient content and the decomposition rate of the organic waste material, and the P-holding capacity of the soil. For more information about using manure for vegetable production, see Using Composted Poultry Manure (Litter) in Mulched Vegetable Production at https://edis.ifas.ufl.edu/ss506 and Introduction to Organic Crop Production at https://edis.ifas.ufl.edu/cv118.

As a soil amendment, compost improves soil's physical, chemical, and biological properties, thus making soil more productive. To eliminate or minimize human and plant pathogens, nematodes, and weed seeds, the composting temperature must be kept in a range from $131^{\circ} \mathrm{F}$ and $170^{\circ} \mathrm{F}$ for 3 days in an in-vessel or static aerated pile. Nitrogen in compost is basically organic. Thus, before being mineralized, compost $\mathrm{N}$ is not as readily bioavailable as synthetic $\mathrm{N}$ fertilizers. Compost $\mathrm{N}$ mineralization rate varies with feedstock, soil characteristics, and composting conditions. Compost $\mathrm{N}$ fertilizer releases only $5 \%$ to $30 \%$ bioavailable $\mathrm{N}$ to crops in the first year. On the contrary, compost $\mathrm{P}$ and $\mathrm{K}$ are as bioavailable as chemical fertilizers. Composting converts raw organic materials to humus-stable forms and hence minimizes possibly adverse impacts on the environment.

\section{Right Place \\ Fertilizer Placement}

Fertilizer rate and placement must be considered together. Banding low amounts of fertilizer too close to plants can result in the same amount of damage as broadcasting excessive amounts of fertilizer in the bed. Because P movement in most soils is minimal, it should be placed in the root zone. Banding is generally considered to provide more efficient utilization of $\mathrm{P}$ by plants than broadcasting. This is especially true on the high P-immobilizing calcareous soils. Where only small amounts of fertilizer $P$ are to be used, it is best to band. If broadcasting $\mathrm{P}$, a small additional amount of starter P near the seed or transplant may improve early growth, especially in cool soils. The modified broadcast method where fertilizer is broadcast only in the bed area provides more efficient use of fertilizer than complete broadcasting.

Micronutrients can be broadcast with the $\mathrm{P}$ and incorporated in the bed area. On the calcareous soils, micronutrients, such as Fe, Mn, and B, should be banded or applied foliarly. Because $\mathrm{N}$ and, to a lesser extent, $\mathrm{K}$ are mobile in sandy soils, they must be managed properly to maximize crop uptake. Plastic mulch helps retain these nutrients in the soil. Under nonmulched systems, split applications of these nutrients must be used to reduce losses to leaching. Hence, up to one-half of the $\mathrm{N}$ and $\mathrm{K}$ may be applied to the soil at planting or shortly after that time. The remaining fertilizer is applied in one or two applications during the early part of the growing season. Split applications also will help reduce the potential for fertilizer burn, which is defined as leaf scorch resulting from overfertilization.

When using plastic mulch, fertilizer placement depends on the type of irrigation system (seepage or drip) and on whether drip tubing or the liquid fertilizer injection wheels are to be used. With seepage irrigation, all $\mathrm{P}$ and micronutrients should be incorporated in the bed. Apply $10 \%$ to $20 \%$ (but not more) of the $\mathrm{N}$ and $\mathrm{K}$ with the $\mathrm{P}$. The remaining $\mathrm{N}$ and $\mathrm{K}$ should be placed in narrow bands on the bed shoulders, the number of which depends on the crop and number of rows per bed. These bands should be placed in shallow (2-to-2 $1 / 2$-inch-deep) grooves. This placement requires that adequate bed moisture be maintained so that capillarity is not broken. Otherwise, fertilizer will not move to the root zone. Excess moisture can result in fertilizer leaching. Fertilizer and water management programs are linked. Maximum fertilizer efficiency is achieved only with close attention to water management. 
In cases where supplemental sidedressing of mulched crops is needed, applications of liquid fertilizer can be made through the mulch with a liquid fertilizer injection wheel. This implement is mounted on a tool bar and, using 30 to 40 psi pressure, injects fertilizer through a hole pierced in the mulch.

\section{Right Time}

\section{Supplemental Fertilizer Applications and BMPs}

In practice, supplemental fertilizer applications, when growing conditions require doing so, allow vegetable growers to stay within BMP guidelines while numerically applying fertilizer rates higher than the standard UF/IFASrecommended rates. The two main growing conditions that may require supplemental fertilizer applications are leaching rains and extended harvest periods. Applying additional fertilizer under the following three circumstances is part of the current UF/IFAS fertilizer recommendations and thus BMPs. Supplemental N and K fertilizer applications may be made if 1) grown on bare ground with seepage irrigation, a $30 \mathrm{lb} / \mathrm{A}$ of $\mathrm{N}$ and/or $20 \mathrm{lb} / \mathrm{A}$ of $\mathrm{K}_{2} \mathrm{O}$ supplemental application is allowed after a leaching rain, defined as when it rains at least 3 inches in 3 days, or 4 inches in 7 days; 2) nutrient levels in the leaf or in the petiole fall below the sufficiency ranges. For bare ground production, the supplemental amount allowed is $30 \mathrm{lb} / \mathrm{A}$ of $\mathrm{N}$ and/or $20 \mathrm{lb} / \mathrm{A}$ of $\mathrm{K}_{2} \mathrm{O}$. For drip-irrigated crops, the supplemental amount allowed is 1.5 to $2.0 \mathrm{lb} / \mathrm{A} /$ day for $\mathrm{N}$ and/or $\mathrm{K}_{2} \mathrm{O}$ for one week; or 3) for economic reasons, the harvest period has to be longer than the typical harvest period. When the results of tissue analysis and/or petiole testing are below the sufficiency ranges, a supplemental $30 \mathrm{lb} / \mathrm{A} \mathrm{N}$ and/or $20 \mathrm{lb} / \mathrm{A}$ of $\mathrm{K}_{2} \mathrm{O}$ may be made for each additional harvest for bare-ground production. For drip-irrigated crops, the supplemental fertilizer application is 1.5 to $2.0 \mathrm{lb} / \mathrm{A} /$ day for $\mathrm{N}$ and/or $\mathrm{K}_{2} \mathrm{O}$ until the next harvest.

\section{Fertigation}

Common irrigation systems used for fertigation include drip, sprinkler, and pivot systems. Advantages of fertigation over conventional fertilizing methods are: 1) more efficient delivery of nutrients, 2) more precise localized application, 3) more flexible control of application rate and timing, and 4) lower application cost. Liquid and water-soluble fertilizers are more commonly used for fertigation than dry fertilizers. The most common liquid $\mathrm{N}$ fertilizers for fertigation are ammonium nitrate (20-0-0), calcium ammonium nitrate (17-0-0), and urea ammonium nitrate (32-0-0). Complete fertilizers (e.g., 8-8-8 and 4-10-10) are also commonly used. For commercial vegetable production in south Florida, a formula of 4-0-8 or 3-0-10 is the most common in fertigation. To develop a more precise fertilizer application strategy, growers can request a custom blend at a local fertilizer dealer based on soil test results and crop nutrient requirements. For more information, consult Fertigation Nutrient Sources and Application Considerations for Citrus at https://edis.ifas.ufl.edu/pdffiles/CH/CH18500. pdf.

The basic components for a fertigation system include a fertilizer tank, an injector, a filter, a pressure regulator, a pressure gauge, and a backflow prevention device. All of the components must be resistant to corrosion. In most situations, $\mathrm{N}$ and $\mathrm{K}$ are the nutrients injected through the irrigation tube. Split applications of $\mathrm{N}$ and $\mathrm{K}$ through the irrigation system offer a means to capture management potential and reduce leaching losses. Other nutrients, such as $\mathrm{P}$, are usually applied to the soil rather than by injection. This is because chemical precipitation can occur with these nutrients and the high calcium carbonate content of our irrigation water in Florida.

Nutrient management through irrigation tubes involves precise scheduling of $\mathrm{N}$ and $\mathrm{K}$ applications. Application rates are determined by crop growth and resulting nutrient demand. Demand early in the season is small, and thus rates of application are small, usually on the order of $1 / 2$ to $3 / 4$ $\mathrm{lb}$ of $\mathrm{N}$ or $\mathrm{K}_{2} \mathrm{O}$ per acre per day. As the crop grows, nutrient demand increases rapidly, so that for some vegetable crops such as tomato the demand might be as high as $2 \mathrm{lb}$ of $\mathrm{N}$ or $\mathrm{K}_{2} \mathrm{O}$ per day. Schedules of $\mathrm{N}$ and $\mathrm{K}$ application have been developed for most vegetables produced with drip irrigation in Florida (Table 7).

\section{Foliar Fertilization}

Foliar fertilization should be used as the last resort for correcting a nutrient deficiency (Table 11). The plant leaf is structured in such a way that it naturally resists infiltration of fertilizer. Foliar fertilization is most appropriate for micronutrients but not appropriate for macronutrients, such as $\mathrm{N}, \mathrm{P}$, and $\mathrm{K}$. In certain situations, temporary deficiencies of $\mathrm{Mn}, \mathrm{Fe}, \mathrm{Cu}$, or $\mathrm{Zn}$ can be corrected by foliar application. For example, micronutrients should be foliar applied in the following situations: (1) In winter when soils are cool and roots cannot extract adequate micronutrients; and (2) in high-pH soils (marl and Rockdale soils) that immobilize broadcast micronutrients. There is a fine line between adequate and toxic amounts of micronutrients. Indiscriminate application of micronutrients may reduce plant growth and yields because of the toxicity. The micronutrients can 
accumulate in the soil and may cause yield and economic losses in vegetable production. If you are not sure if your crop requires micronutrients or how much you should apply, contact your UF/IFAS Extension county agent.

\section{The 5th R, Right Irrigation}

Fertilization and irrigation go hand in hand, with fertilizers included in irrigation schedules and systems. Water is the solvent of all nutrients and the carrier of almost every pollutant. Keeping moisture and fertilizer primarily in the root zone by managing irrigation inputs and drainage minimizes nutrient-related impacts. Irrigating in excess of the soil's water-holding capacity or excessive drainage leads to increased runoff or leaching and may result in greater production costs or smaller marketable yields.

Table 1. A general guideline to crop tolerance of mineral soil acidity. ${ }^{1}$

\begin{tabular}{|c|c|c|c|c|}
\hline \multicolumn{2}{|c|}{ Slightly Tolerant (pH 6.8-6.0) } & \multicolumn{2}{|c|}{ Moderately Tolerant (pH 6.8-5.5) } & \multirow{2}{*}{$\begin{array}{c}\text { Very Tolerant (pH 6.8-5.0) } \\
\text { Endive }\end{array}$} \\
\hline Beet & Leek & Bean, lima & Mustard & \\
\hline Broccoli & Lettuce & Bean, snap & Pea & Potato \\
\hline Cabbage & Muskmelon & Brussels sprouts & Pepper & Shallot \\
\hline Cauliflower & Okra & Carrot & Pumpkin & Sweet potato \\
\hline Celery & Onion & Collard & Radish & Watermelon \\
\hline \multirow[t]{4}{*}{ Chard } & Spinach & Corn & Squash & \\
\hline & & Cucumber & Strawberry & \\
\hline & & Eggplant & Tomato & \\
\hline & & Kale & Turnip & \\
\hline
\end{tabular}

Table 2. Liming materials.

\begin{tabular}{|c|c|c|c|}
\hline Material & Formula & $\begin{array}{l}\text { Amount of Material to Be Used to } \\
\text { Equal } 1 \text { ton of Calcium Carbonate }\end{array}$ & $\begin{array}{l}\text { Neutralizing } \\
\text { Value }^{2}(\%)\end{array}$ \\
\hline Calcium carbonate, calcite, hi-cal lime & $\mathrm{CaCO}_{3}$ & $2,000 \mathrm{lb}$ & 100 \\
\hline Calcium-magnesium carbonate, dolomite & $\mathrm{CaCO}_{3}, \mathrm{MgCO}_{3}$ & $1,850 \mathrm{lb}$ & 109 \\
\hline Calcium oxide, burnt lime & $\mathrm{CaO}$ & $1,100 \mathrm{lb}$ & 179 \\
\hline Calcium hydroxide, hydrated lime & $\mathrm{Ca}(\mathrm{OH})_{2}$ & $1,500 \mathrm{lb}$ & 136 \\
\hline Calcium silicate, slag & $\mathrm{CaSiO}_{3}$ & $2,350 \mathrm{lb}$ & 86 \\
\hline Magnesium carbonate & $\mathrm{MgCO}_{3}$ & $1,680 \mathrm{lb}$ & 119 \\
\hline
\end{tabular}


Table 3. Effect of some fertilizer materials on soil pH.

\begin{tabular}{|l|c|}
\hline Fertilizer Material & $\begin{array}{l}\text { Approximate Calcium } \\
\text { Carbonate Equivalent (lb)' }\end{array}$ \\
\hline Ammonium nitrate & -1200 \\
\hline Ammonium sulfate & -2200 \\
\hline Anhydrous ammonia & -3000 \\
\hline Diammonium phosphate & -1250 to -1550 \\
\hline Potassium chloride & 0 \\
\hline Sodium-potassium nitrate & +550 \\
\hline Nitrogen solutions & -759 to -1800 \\
\hline Normal (ordinary) superphosphate & 0 \\
\hline Potassium nitrate & +520 \\
\hline Potassium sulfate & 0 \\
\hline Potassium-magnesium sulfate & 0 \\
\hline Triple (concentrated) superphosphate & 0 \\
\hline Urea & -1700 \\
\hline 'A minus sign indicates the number of pounds of calcium carbonate needed to neutralize the acid formed when one ton of fertilizer is added to the soil. & \\
\hline
\end{tabular}

Table 4. Nutrient elements required by plants.

\begin{tabular}{|c|c|c|c|}
\hline & Nutrient & Deficiency Symptoms & Occurrence \\
\hline \multirow[t]{3}{*}{ Macronutrients } & Nitrogen $(\mathrm{N})$ & $\begin{array}{l}\text { Stems thin, erect, hard. Leaves small, yellow; on some } \\
\text { crops (tomatoes) undersides are reddish. Lower leaves } \\
\text { affected first. }\end{array}$ & $\begin{array}{l}\text { On sandy soils especially after heavy rain or after } \\
\text { overirrigation. Also on organic soils during cool growing } \\
\text { seasons. }\end{array}$ \\
\hline & Phosphorus (P) & $\begin{array}{l}\text { Stems thin and shortened. Leaves develop purple color. } \\
\text { Older leaves affected first. Plants stunted and maturity } \\
\text { delayed. }\end{array}$ & $\begin{array}{l}\text { On acidic soils or very basic soils. Also when soils are } \\
\text { cool and wet. }\end{array}$ \\
\hline & Potassium (K) & $\begin{array}{l}\text { Older leaves develop gray or tan areas on leaf margins. } \\
\text { Eventually a scorch appears on the entire margin. }\end{array}$ & On sandy soils following leaching rains or overirrigation. \\
\hline \multirow[t]{3}{*}{$\begin{array}{l}\text { Secondary } \\
\text { nutrients }\end{array}$} & Calcium (Ca) & $\begin{array}{l}\text { Growing-point growth restricted on shoots and roots. } \\
\text { Specific deficiencies include blossom-end rot of tomato, } \\
\text { pepper and watermelon, brown heart of escarole, celery } \\
\text { blackheart, and cauliflower or cabbage tip burn. }\end{array}$ & On strongly acidic soils, or during severe droughts. \\
\hline & Magnesium (Mg) & $\begin{array}{l}\text { Initially older leaves show yellowing between veins, } \\
\text { followed by yellowing of young leaves. Older leaves } \\
\text { soon fall. }\end{array}$ & On strongly acidic soils, or on leached sandy soils. \\
\hline & Sulfur (S) & General yellowing of younger leaves and growth. & $\begin{array}{l}\text { On very sandy soils, low in organic matter, reduced } \\
\text { especially following continued use of sulfur-free } \\
\text { fertilizers and especially in areas that receive little } \\
\text { atmospheric sulfur. }\end{array}$ \\
\hline \multirow[t]{8}{*}{ Micronutrients } & Boron (B) & $\begin{array}{l}\text { Growing tips die and leaves are distorted. Specific } \\
\text { diseases caused by boron deficiency include brown curd } \\
\text { and hollow stem of cauliflower, cracked stem of celery, } \\
\text { blackheart of beet, and internal browning of turnip. }\end{array}$ & $\begin{array}{l}\text { On soils with pH above } 6.8 \text { or on sandy, leached soils, or } \\
\text { on crops with very high demand such as cole crops. }\end{array}$ \\
\hline & Copper (Cu) & $\begin{array}{l}\text { Yellowing of young leaves, stunting of plants. Onion } \\
\text { bulbs are soft with thin, pale scales. }\end{array}$ & On organic soils or occasionally new mineral soils. \\
\hline & Chlorine $(\mathrm{Cl})$ & Deficiencies very rare. & Usually only under laboratory conditions. \\
\hline & Iron (Fe) & $\begin{array}{l}\text { Distinct yellow or white areas between veins on } \\
\text { youngest leaves. }\end{array}$ & On soils with pH above 6.8 . \\
\hline & Manganese (Mn) & $\begin{array}{l}\text { Yellow mottled areas between veins on youngest leaves, } \\
\text { not as intense as iron deficiency. }\end{array}$ & On soils with pH above 6.4 . \\
\hline & Molybdenum (Mo) & $\begin{array}{l}\text { Pale, distorted, narrow leaves with some interveinal } \\
\text { yellowing of older leaves, e.g., whiptail disease of } \\
\text { cauliflower. Rare. }\end{array}$ & On very acidic soils. \\
\hline & Nickel (Ni) & Deficiencies very rare. & Usually only under laboratory conditions. \\
\hline & Zinc (Zn) & $\begin{array}{l}\text { Small reddish spots on cotyledon leaves of beans; light } \\
\text { areas (white bud) of corn leaves. }\end{array}$ & \\
\hline
\end{tabular}


Table 5. Target $\mathrm{pH}$ and nitrogen (N) fertilization recommendations for selected vegetable crops in mineral soils of Florida.

\begin{tabular}{|l|c|c|}
\hline \multicolumn{1}{|c|}{ Crops } & \multicolumn{1}{|c|}{ Target pH } & N (Ib/acre) \\
\hline Tomato, pepper, potato, celery, sweet corn, crisphead lettuce, endive, escarole, romaine lettuce, and eggplant & 6.0 (potato) and 6.5 & 200 \\
\hline Snapbean, lima bean, and pole bean & 6.5 \\
\hline Broccoli, cauliflower, brussels sprouts, cabbage, collards, Chinese cabbage, and carrots & 6.5 \\
\hline Radish and spinach & 6.5 \\
\hline Cucumber, squash, pumpkin, muskmelon, leaf lettuce, sweet bulb onion, watermelon, and strawberry & 100 & 175 \\
\hline Southernpea, snowpea, English pea, and sweet potato & 9.0 (watermelon) and \\
\hline Kale, turnip, mustard, parsley, okra, bunching onion, leek, and beet & 6.5 \\
\hline
\end{tabular}

Table 6. Mehlich-1 (double-acid) and Mehlich-3 interpretations for vegetable crops in Florida.

\begin{tabular}{|c|c|c|c|c|c|c|c|c|}
\hline \multirow{3}{*}{\begin{tabular}{|l|} 
\\
Nutrient \\
\end{tabular}} & \multicolumn{5}{|c|}{ Mehlich-1 (Double-Acid) Interpretations } & \multicolumn{3}{|c|}{ Mehlich-3 Interpretations } \\
\hline & Very Low & Low & Medium & High & Very High & Low & Medium & High \\
\hline & \multicolumn{5}{|c|}{ (parts per million soil) } & \multicolumn{3}{|c|}{ (parts per million soil) } \\
\hline$P$ & $<10$ & $10-15$ & $16-30$ & $31-60$ & $>60$ & $\leq 25$ & $26-45$ & $>45$ \\
\hline 5 & $<20$ & $20-35$ & $36-60$ & $61-125$ & $>125$ & $\leq 35$ & $36-60$ & $>60$ \\
\hline $\mathrm{Mg}^{1}$ & $<10$ & $10-20$ & $21-40$ & $41-60$ & $>60$ & $\leq 20$ & $21-40$ & $>40$ \\
\hline $\mathrm{Ca}^{2}$ & $<100$ & $100-200$ & $201-300$ & $301-400$ & $>400$ & & & \\
\hline
\end{tabular}

Table 7. Phosphorus ( $\mathrm{P}$, expressed as $\mathrm{P}_{2} \mathrm{O}_{5}$ ) and potassium ( $\mathrm{K}$, expressed as $\mathrm{K}_{2} \mathrm{O}$ ) fertigation recommendations for selected vegetable crops in mineral soils for Florida based on low, medium, and high soil test index using Mehlich-3 soil extraction method.

\begin{tabular}{|c|c|c|c|c|c|c|}
\hline & \multicolumn{3}{|c|}{$\mathbf{P}_{2} \mathbf{O}_{5}$} & \multicolumn{3}{|c|}{$\mathrm{K}_{2} \mathrm{O}$} \\
\hline & Low & Medium & High & Low & Medium & High \\
\hline & \multicolumn{3}{|c|}{ (Ib/A/crop season) } & \multicolumn{3}{|c|}{ (Ib/A/crop season) } \\
\hline Celery & $150-200$ & 100 & 0 & $150-250$ & 100 & 0 \\
\hline Eggplant & $130-160$ & 100 & 0 & $130-160$ & 100 & 0 \\
\hline $\begin{array}{l}\text { Broccoli, cauliflower, brussels sprouts, cabbage, collards, Chinese } \\
\text { cabbage, carrots, kale, turnip, mustard, parsley, okra, muskmelon, } \\
\text { leaf lettuce, sweet bulb } \\
\text { onion, watermelon, pepper, sweet corn, crisphead lettuce, endive, } \\
\text { escarole, strawberry, and romaine lettuce }\end{array}$ & $120-150$ & 100 & 0 & $120-150$ & 100 & 0 \\
\hline Tomato & $120-150$ & 100 & 0 & $125-150$ & 100 & 0 \\
\hline $\begin{array}{l}\text { Cucumber, squash, pumpkin, snapbean, lima bean, pole bean, beet, } \\
\text { radish, spinach, and sweet potato }\end{array}$ & $100-120$ & 80 & 0 & $100-120$ & 80 & 0 \\
\hline Bunching onion and leek & $100-120$ & 100 & 0 & $100-120$ & 100 & 0 \\
\hline Potato $^{1}$ & 120 & 100 & 0 & 150 & -- & -- \\
\hline Southern pea, snowpea, and English pea & 80 & 80 & 0 & 80 & 60 & 0 \\
\hline
\end{tabular}


Table 8. Fertigation ${ }^{1}$ and supplemental fertilizer ${ }^{1}$ recommendations on mineral soils testing low in potassium $\left(\mathrm{K}_{2} \mathrm{O}\right)$ based on the Mehlich-3 soil extraction method.

\begin{tabular}{|c|c|c|c|c|c|c|c|c|}
\hline & $\begin{array}{l}\text { Preplant }^{2} \\
\text { (Ib/A) }\end{array}$ & \multicolumn{5}{|c|}{ Injected $^{3}$ (Ib/A/day) } & $\begin{array}{l}\text { Low Plant } \\
\text { Content }{ }^{4,5}\end{array}$ & $\begin{array}{l}\text { Extended } \\
\text { Season } 4,6 \\
\text { (Ib/A/day) }\end{array}$ \\
\hline \multicolumn{9}{|l|}{ Eggplant } \\
\hline Wk after transplanting ${ }^{7}$ & & $1-2$ & $3-4$ & $5-10$ & $11-13$ & & & \\
\hline $\mathrm{N}$ & $0-70$ & 1.5 & 2.0 & 2.5 & 2.0 & & $1.5-2.0$ & $1.5-2.0$ \\
\hline $\mathrm{K}_{2} \mathrm{O}$ & $0-55$ & 1.0 & 1.5 & 2.5 & 1.5 & & $1.5-2.0$ & $1.5-2.0$ \\
\hline \multicolumn{9}{|l|}{ Okra } \\
\hline Wk after transplanting & & $1-2$ & $3-4$ & $5-12$ & 13 & & & \\
\hline $\mathrm{N}$ & $0-40$ & 1.0 & 1.5 & 2.0 & 1.5 & & $1.5-2.0$ & $1.5-2.0$ \\
\hline $\mathrm{K}_{2} \mathrm{O}$ & $0-50$ & 1.0 & 1.5 & 2.0 & 1.5 & & $1.5-2.0$ & $1.5-2.0$ \\
\hline \multicolumn{9}{|l|}{ Pepper } \\
\hline Wk after transplanting & & $1-2$ & $3-4$ & $5-11$ & 12 & 13 & & \\
\hline $\mathrm{N}$ & $0-70$ & 1.5 & 2.0 & 2.5 & 2.0 & 1.5 & $1.5-2.0$ & $1.5-2.0$ \\
\hline $\mathrm{K}_{2} \mathrm{O}$ & $0-70$ & 1.5 & 2.0 & 2.5 & 2.0 & 1.5 & $1.5-2.0$ & $1.5-2.0$ \\
\hline \multicolumn{9}{|l|}{ Strawberry } \\
\hline Wk after transplanting & & $1-2$ & Sept.-Jan. & Feb.-Mar. & Apr. & & & \\
\hline$N$ & $0-40$ & 0.3 & 0.6 & 0.75 & 0.6 & & $0.6-0.75$ & $0.6-0.75$ \\
\hline $\mathrm{K}_{2} \mathrm{O}$ & $0-40$ & 0.3 & 0.5 & 0.75 & 0.6 & & $0.6-0.75$ & $0.6-0.75$ \\
\hline \multicolumn{9}{|l|}{ Tomato $^{8}$} \\
\hline Wk after transplanting & & $1-2$ & $3-4$ & $5-11$ & 12 & 13 & & \\
\hline $\mathrm{N}$ & $0-70$ & 1.5 & 2.0 & 2.5 & 2.0 & 1.5 & $1.5-2.0$ & $1.5-2.0$ \\
\hline $\mathrm{K}_{2} \mathrm{O}$ & $0-70$ & 1.5 & 2.0 & 2.5 & 2.0 & 1.5 & $1.5-2.0$ & $1.5-2.0$ \\
\hline \multicolumn{9}{|c|}{$\begin{array}{l}{ }^{1} \mathrm{~A}=7,260 \text { linear feet per acre (6-ft bed spacing); for soils testing "low" in Mehlich-3 potassium }\left(\mathrm{K}_{2} \mathrm{O}\right) \text {, seeds and transplants may benefit from applications of a } \\
\text { starter solution at a rate no greater than } 10 \text { to } 15 \mathrm{Ib} / \mathrm{A} \text { for } \mathrm{N} \text { and } \mathrm{P}_{2} \mathrm{O}_{5} \text { and applied through the plant hole or near the seeds. } \\
{ }^{2} \mathrm{Applied} \text { using the modified broadcast method (fertilizer is broadcast where the beds will be formed only, and not over the entire field). Preplant fertilizer canno } \\
\text { be applied to double/triple crops because of the plastic mulch; hence, in these cases, all the fertilizer has to be injected. } \\
{ }^{3} \text { This fertigation schedule is applicable when no } \mathrm{N} \text { and } \mathrm{K}_{2} \mathrm{O} \text { are applied preplant. Reduce schedule proportionally to the amount of } \mathrm{N} \text { and } \mathrm{K}_{2} \mathrm{O} \text { applied preplant. } \\
\text { Fertilizer injections may be done daily or weekly. Inject fertilizer at the end of the irrigation event and allow enough time for proper flushing afterwards. } \\
{ }^{4} \text { Plant nutritional status may be determined with tissue analysis or fresh petiole-sap testing, or any other calibrated method. The "low" diagnosis needs to be } \\
\text { based on UF/IFAS interpretative thresholds. } \\
{ }^{5} \text { Plant nutritional status must be diagnosed every week to repeat supplemental fertilizer application. } \\
{ }^{6} \text { Supplemental fertilizer applications are allowed when irrigation is scheduled following a recommended method (see Evapotranspiration-Based Irrigation } \\
\text { Scheduling for Agriculture at https://edis.ifas.ufl.edu/ae457). Supplemental fertilizations are to be applied in addition to base fertilization when appropriate. } \\
\text { Supplemental fertilization is not to be applied "in advance" with the preplant fertilizer. } \\
{ }^{7} \text { For standard 13-week-long transplanted tomato crop. } \\
{ }^{8} \text { Some of the fertilizer may be applied with a fertilizer wheel through the plastic mulch during the tomato crop when only part of the recommended base rate is } \\
\text { applied preplant. Rate may be reduced when a controlled-release fertilizer source is used. }\end{array}$} \\
\hline
\end{tabular}

Table 9. Phosphorus ( $\mathrm{P}$; expressed as $\mathrm{P}_{2} \mathrm{O}_{5}$ ) and potassium ( $\mathrm{K}$; expressed as $\mathrm{K}_{2} \mathrm{O}$ ) fertilization recommendations for selected vegetable crops in mineral soils of Florida, using Mehlich-1 soil extractant method. VL, L, M, H, and VH = very low, low, medium, high, and very high, respectively.

\begin{tabular}{|c|c|c|c|c|c|c|c|c|c|c|}
\hline & \multicolumn{5}{|c|}{$\mathrm{P}_{2} \mathrm{O}_{5}$} & \multicolumn{5}{|c|}{$\mathrm{K}_{2} \mathrm{O}$} \\
\hline & VL & $\mathbf{L}$ & M & $\mathbf{H}$ & VH & VL & $\mathbf{L}$ & M & $\mathbf{H}$ & VH \\
\hline & \multicolumn{5}{|c|}{ (Ib/A/crop season) } & \multicolumn{5}{|c|}{ (lb/A/crop season) } \\
\hline Celery & 200 & 150 & 100 & 0 & 0 & 250 & 150 & 100 & 0 & 0 \\
\hline Eggplant & 160 & 130 & 100 & 0 & 0 & 160 & 130 & 100 & 0 & 0 \\
\hline $\begin{array}{l}\text { Broccoli, cauliflower, Brussels sprouts, cabbage, collards, } \\
\text { Chinese cabbage, carrots, kale, turnip, mustard, parsley, okra, } \\
\text { muskmelon, leaf lettuce, sweet bulb onion, watermelon, } \\
\text { pepper, sweet corn, crisphead lettuce, endive, escarole, } \\
\text { strawberry, and romaine lettuce }\end{array}$ & 150 & 120 & 100 & 0 & 0 & 150 & 120 & 100 & 0 & 0 \\
\hline Tomato & 150 & 120 & 100 & 0 & 0 & 225 & 150 & 100 & 0 & 0 \\
\hline $\begin{array}{l}\text { Cucumber, squash, pumpkin, snapbean, lima bean, pole bean, } \\
\text { beet, radish, spinach, and sweet potato }\end{array}$ & 120 & 100 & 80 & 0 & 0 & 120 & 100 & 80 & 0 & 0 \\
\hline Bunching onion and leek & 120 & 100 & 100 & 0 & 0 & 120 & 100 & 100 & 0 & 0 \\
\hline Potato & 120 & 120 & 60 & 0 & 0 & 150 & -- & -- & -- & -- \\
\hline Southern pea, snowpea, and English pea & 80 & 80 & 60 & 0 & 0 & 80 & 80 & 60 & 0 & 0 \\
\hline
\end{tabular}


Table 10. Interpretations of Mehlich-1 soil tests for micronutrients.

\begin{tabular}{|c|c|c|c|}
\hline & \multicolumn{3}{|c|}{ Soil pH (Mineral Soils Only) } \\
\hline & $5.5-5.9$ & $6.0-6.4$ & 6.5-7.0 \\
\hline & \multicolumn{3}{|c|}{ (parts per million) } \\
\hline Test level below which there may be a crop response to applied copper & $0.1-0.3$ & $0.3-0.5$ & 0.5 \\
\hline Test level above which copper toxicity may occur & $2.0-3.0$ & $3.0-5.0$ & 5.0 \\
\hline Test level below which there may be a crop response to applied manganese & $3.0-5.0$ & $5.0-7.0$ & $7.0-9.0$ \\
\hline Test level below which there may be a crop response to applied zinc & 0.5 & $0.5-1.0$ & $1.0-3.0$ \\
\hline
\end{tabular}

Table 11. Some nutrients and fertilizer management for vegetable production in Florida.

\begin{tabular}{|l|l|c|}
\hline Nutrient & Source & Foliar Application (lb Product/A) \\
\hline Boron & $\begin{array}{l}\text { Borax' } \\
\text { Solubor }\end{array}$ & 2 to 5 \\
1 to 1.5 \\
\hline Copper & Copper sulfate & 2 to 5 \\
\hline Iron & $\begin{array}{l}\text { Ferrous sulfate } \\
\text { Chelated iron }\end{array}$ & 2 to 3 \\
\hline & Manganous sulfate & 2 to 4 \\
\hline Manganese & Sodium molybdate & 0.25 to 0.50 \\
\hline Molybdenum & Zinc sulfate & 2 to 4 \\
\hline Zinc & Chelated zinc & 0.75 to 1 \\
\hline Calcium & $\begin{array}{l}\text { Calcium chloride } \\
\text { Calcium nitrate }\end{array}$ & 5 to 10 \\
\hline Magnesium & Magnesium sulfate & 5 to 10 \\
\hline 1 Mention of a trade name does not imply a recommendation over similar materials. & 10 to 15 \\
\hline
\end{tabular}

